\title{
Differences Of Still Birth Rate Between Cesarean Section And Normal Vaginal Delivery in Al-Nasiriyah At 2019: A Comparative Study
}

\author{
Falah Abd Basher Al-Hamdani DCH
}

Khudhair Abbas Salih DCH

Suad Saddam Salih DGO

\begin{abstract}
$\underline{\text { Abstract }}$
Background: A born baby with no any life signs within or after 28 weeks of gestation is define as stillbirth, . $3_{\text {rd }}$ trimester SB account 2.6 million globally at 2015 .

Objectives: to compare SBR by the 2 places of birth in Al-Nasiriyah city, and to determine the expected determinants of the still birth.

Methodology: An analytical-comparative, hospital based study, extending all over the past 1 years; from $1^{\text {st }}$ day of January till the end of December of 2019 in Bint Al-Huda maternity and pediatrics hospital-Thi-qar/Iraq. Including all Still birth, from 2 different places of labor that including: Main labor room and operative theater room, informed consent also was taken from all participants parent. SPSS version 25 had been used, $\mathrm{P}$ value $<0.05$ is considered significant.
\end{abstract}

Results: Among 8772 delivered fetus as a normal vaginal delivery, 136 delivered died with a total still birth rate of $15.5 / 1000$, compared to a total deliveries by cesarean section of 5810 , were the total still birth of 97 delivered died with a rate of 16.7/1000.Still birth rates difference was of not a great values in their distribution according to different months and seasons of the year 2019. Age of the parents and weight of SB had a significant role in SBR.

Conclusion: delivery by CS and NVD show no significant statistical difference of the SBR between those who are., also no difference in monthly trends of SBR all-over the period of the study, whether was by CS or NVD. Different age groups in different places and within the same place show a highly significant statistical association, B. wt. of deliverd baby was also one of the main determinants of the SBR and the age of father that extending the 41 years show significant difference in the occurance of the SB.

\section{$\underline{\text { Introduction }}$}

A born baby with no any life signs within or after 28 weeks of gestation is define as stillbirth $(\mathrm{SB})^{(1)} \cdot 3^{\text {rd }}$ trimester $\left(3^{\text {rd }} \mathrm{T}\right)$ SB account 2.6 million globally at 2015, countries of low \& middle income are the most affected regions., nearly $75 \%$ in subSaharan Africa \& south Asia ${ }^{(2)}$. Where this number approximately greater by ten times than that for developed countries $(29 / 1000$ versus $3 / 1000$ of total births) ${ }^{(2)}$. The $2^{\text {nd }} \mathrm{T}$ 
Web Site: https://jmed.utq.edu.iq

ISSN (Print):1992-92 18, ISSN (Online):1992-92 18

DOI: https://doi.org/10.32792/utq/utjmed/19/1/13
Email:utjmed@utq.edu.iq
SB number is unknown in the in LMICs but in high-income countries(HIC) nearly $1 / 2$ of all SB occur from 20 -28 weeks of pregnancy $^{(2)}$.

In LMIC, the High SB rates might be contributed to several proximal, intermediate \& distal factors ,that tended to be crossly related $^{(3)}$. Potential factors that consider as a distal involve poorly educated women, low SES, \& the seeking care time is inappropriate. While intermediate factors for SB expressed as young or extreme age of reproduction of mother, lackness or poorly aware of danger signs awareness, community resources- non-availability, hospital transfer or referral delay, and maternal malnutrition (poverty) ${ }^{(4,5)}$. Finally, proximal factors: medical conditions for both fetal \& mother and health care system poor response act for SB. These factors inter-relatedness exampled as, illiteracy plus poverty, where correlated with food insecurity, malnutrition plus anemia. also affect a seeking care family's decisions if they identifying the danger signs, and antenatal care access inform delivery, or emergency care. For the poorly resourced- countries, even when time of reach to facility is proper for saving life of both the inadequate facilities are fail to prevent poorly progress fetal or meternal outcomes ${ }^{(6)}$.

many literatures emphasized that the determinants of deaths clinical cause for maternal \& SB are hospitals occurrence .

Global analyses, recently, over the past five years, suggest overall decline in SBR was $25.5 \%$, A big variations in SBR exist among LMIC, and many ofthese countries have experienced little or no reduction in $\mathrm{SBR}^{(7,8)}$.

The intra-partum period is the main period for the fetal deaths occurance, where most of these occur in near term or at term, by which the the maternal causes were the main contributors of mortality. The surprising point was that $2 / 3$ of the $\mathrm{SB}$ were with no any maternal complication during their gestation and before labor ${ }^{(2)}$.

Many risk factoers across LMIC playing a big role in the resistant of these high $\mathrm{SBR}^{(3)}$. That are of varying incidences across countries, where resources availability \& care provision are the main determinants. A populations that are remotely located not getting a accessible care at proper time. Poor a registration vital statistics functionality had a relation for high $\mathrm{SBR}^{(3,7)}$. Data at National levels are rarely available regarding some countries In LMICs, surveys for health \& demography were have not included SBs as routine pregnancy outcomes, if the information is available, it is of poor validation regarding age of gestation ${ }^{(8,9)}$. A hospital-based data regarding the SB are the main dependent information for many countries $^{(10-12)}$.

This article aimed to determine the comparative main suspected determinants of still birth in two different localities of birth in the hospital of the study inform of intermediate \& distal risk factors and also to be compared with SBR of other societies.

Aim of the study: to compare SBR by the 2 places of birth in Al-Nasiriyah city, and to determine the expected determinants of the still birth.

Methodology \& Type of study: A The study was an analytical-comparative, hospital based study, extending all over the past 1 years; from $1^{\text {st }}$ day of January till the end of December of 2019 in Bint Al-Huda maternity and pediatrics hospital-Thiqar-Iraq.

\section{Study population:}

All Still birth had been included, from 2 different places of labor that including: Main labor room and operative theater room 
Web Site: https://jmed.utq.edu.iq

ISSN (Print):1992-92 18, ISSN (Online):1992-92 18

DOI: https://doi.org/10.32792/utq/utjmed/19/1/13

\section{Inclusion and exclusion criteria:}

All SBs regardless to their gender or age were included, those who died after birth were excluded.

\section{Variables of interest:}

1-Age for the mother and father that divided into three categories ( $<20 \mathrm{yrs}, 20-40 \mathrm{yrs}$ and $>$ $40 \mathrm{yrs}$ ) , 2-Sex that resorted into male and females. 3.Residence into: Al-Nasiriyah and others. 3-Months of death as documented in the case sheet of the mother. 4Presence of congenital anomalies. 5- Ward of labor by which the neonate had been died and death registered. 6- Weight of delivered still birth $(<1 \mathrm{Kg}, 1-2.5 \mathrm{Kg}$ and $>2.5 \mathrm{Kg})$.

\section{Ethical considerations:}

An ethical clearance was obtained from Bint Al-Huda teaching hospital directorate to perform the study. An informed consent also was taken from all participants parent.

\section{Pilot study :}

To know the feasibility, cost and time required for the final study and also know the adequacy of the questionnaire and the extent of any unexpected problems, a piloting was carried out during the first two weeks of January 2019on ten

Procedures of recording, coding and checking of data :

The data

\section{Email:utjmed@utq.edu.iq}

directly registered in the questionnaire form at the work field and checked daily and weekly . A quantitative approach was used for coding and the questionnaire data was pre-coded by using of statistical package for social science (SPSS)version ( 25) .

\section{Statistical analysis:}

Excel sheet, SPSS version (25) was used for data analysis . descriptive statistic , frequencies, percentages, associations, tests of significance ( Paired $t$ test ) was used for

analysis of quantitative- continuous variables . means and standard deviations were used to present data of continuous variables. Correlation was performed to recognize the independent predictors of SBR. A P-value < 0.05 was considered statistically significant .

Epidemiological analysis:

Including estimation of still birth rate $=$ Number of all delivered died fetus/total number of deliveries* 1000

At specific place and time.

\section{Results:}

Among 8772 delivered fetus as a normal vaginal delivery, 136 delivered died with a total still birth rate of $15.5 / 1000$, compared to a total deliveries by cesarean section of 5810 , were the total still birth of 97 delivered died with a rate of $16.7 / 1000$.

Still birth rates difference was of not a great values in their distribution according to different months and seasons of the year 2019 , as shown in figure 1 and table 1. 
Web Site: https://jmed.utq.edu.iq

ISSN (Print):1992-92 18, ISSN (Online):1992-92 18

DOI: https://doi.org/10.32792/utq/utjmed/19/1/13
Email:utjmed@utq.edu.iq

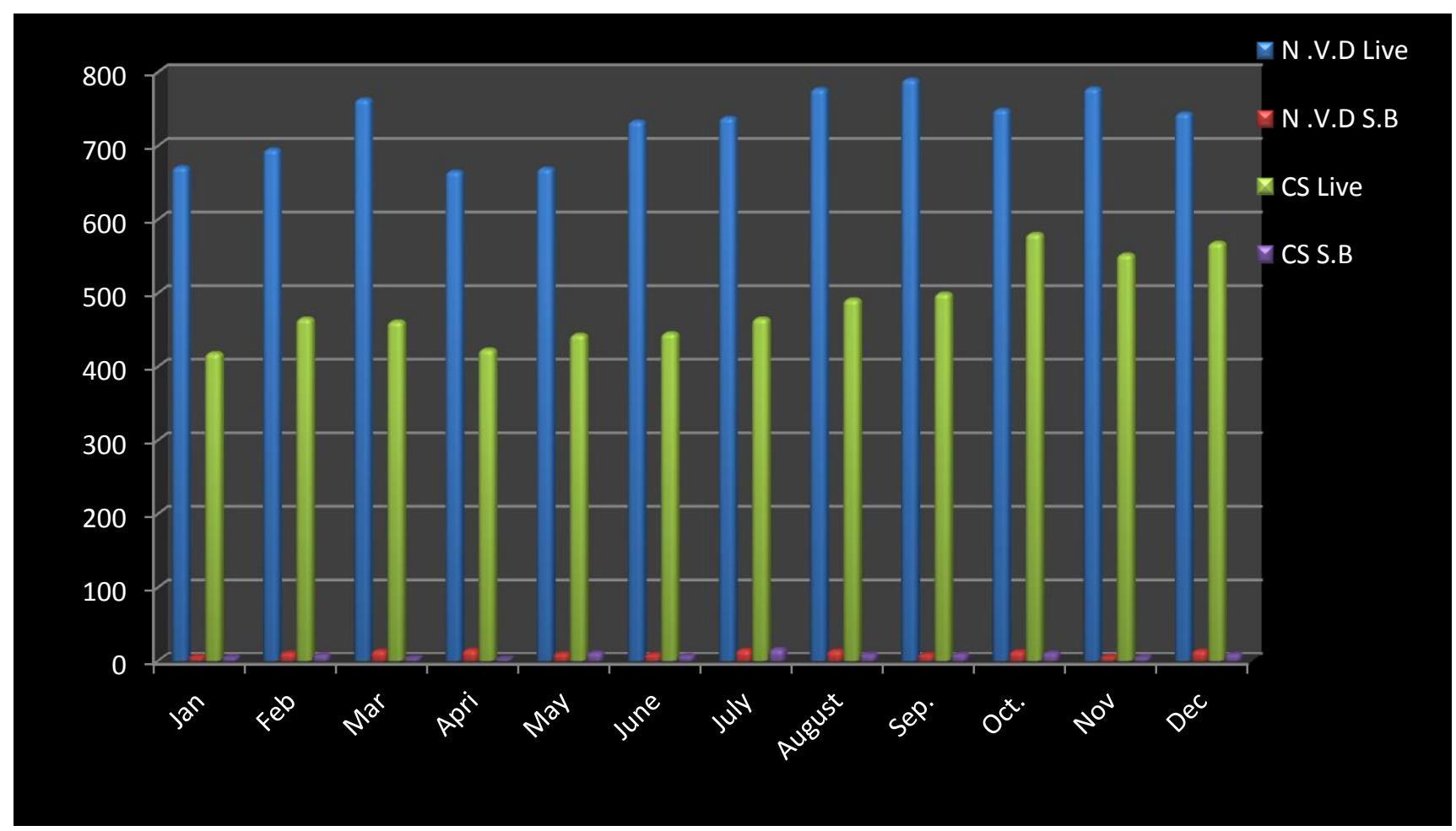

Figure 1: Distribution according to month of the year 2019

Table 1: Still birth number and rate according to places of delivery and months of 2019

\begin{tabular}{|c|c|c|c|c|c|c|}
\hline \multirow[t]{2}{*}{ Months } & \multicolumn{3}{|c|}{ Normal Vaginal Deliveries } & \multicolumn{3}{|c|}{ Cesarean Section } \\
\hline & $\begin{array}{l}\text { Total } \\
\text { birth }\end{array}$ & S.B & S.B. rate & $\begin{array}{l}\text { Total } \\
\text { birth }\end{array}$ & S.B & S.B. rate \\
\hline Jan & 671 & 6 & 8.941878 & 418 & 5 & 11.96172 \\
\hline Feb & 695 & 11 & 15.82734 & 465 & 8 & 17.2043 \\
\hline Mar & 763 & 14 & 18.34862 & 461 & 4 & 8.67679 \\
\hline Apri & 665 & 15 & 22.55639 & 423 & 3 & 7.092199 \\
\hline May & 669 & 10 & 14.94768 & 443 & 11 & 24.8307 \\
\hline June & 733 & 9 & 12.27831 & 445 & 7 & 15.73034 \\
\hline July & 738 & 15 & 20.3252 & 465 & 16 & 34.4086 \\
\hline August & 777 & 14 & 18.01802 & 491 & 9 & 18.32994 \\
\hline Sep. & 790 & 9 & 11.39241 & 499 & 9 & 18.03607 \\
\hline Oct. & 749 & 13 & 17.35648 & 580 & 11 & 18.96552 \\
\hline Nov & 778 & 6 & 7.712082 & 552 & 5 & 9.057971 \\
\hline Dec & 744 & 14 & 18.8172 & 568 & 9 & 15.84507 \\
\hline Total & 8772 & 136 & 15.50388 & 5810 & 97 & 16.69535 \\
\hline
\end{tabular}


ISSN (Print):1992-92 18, ISSN (Online):1992-92 18

DOI: https://doi.org/10.32792/utq/utjmed/19/1/13

There was no significant statistical difference of the SBR with in the 2 places of delivery, where $\mathrm{P}$ value 0.382 .

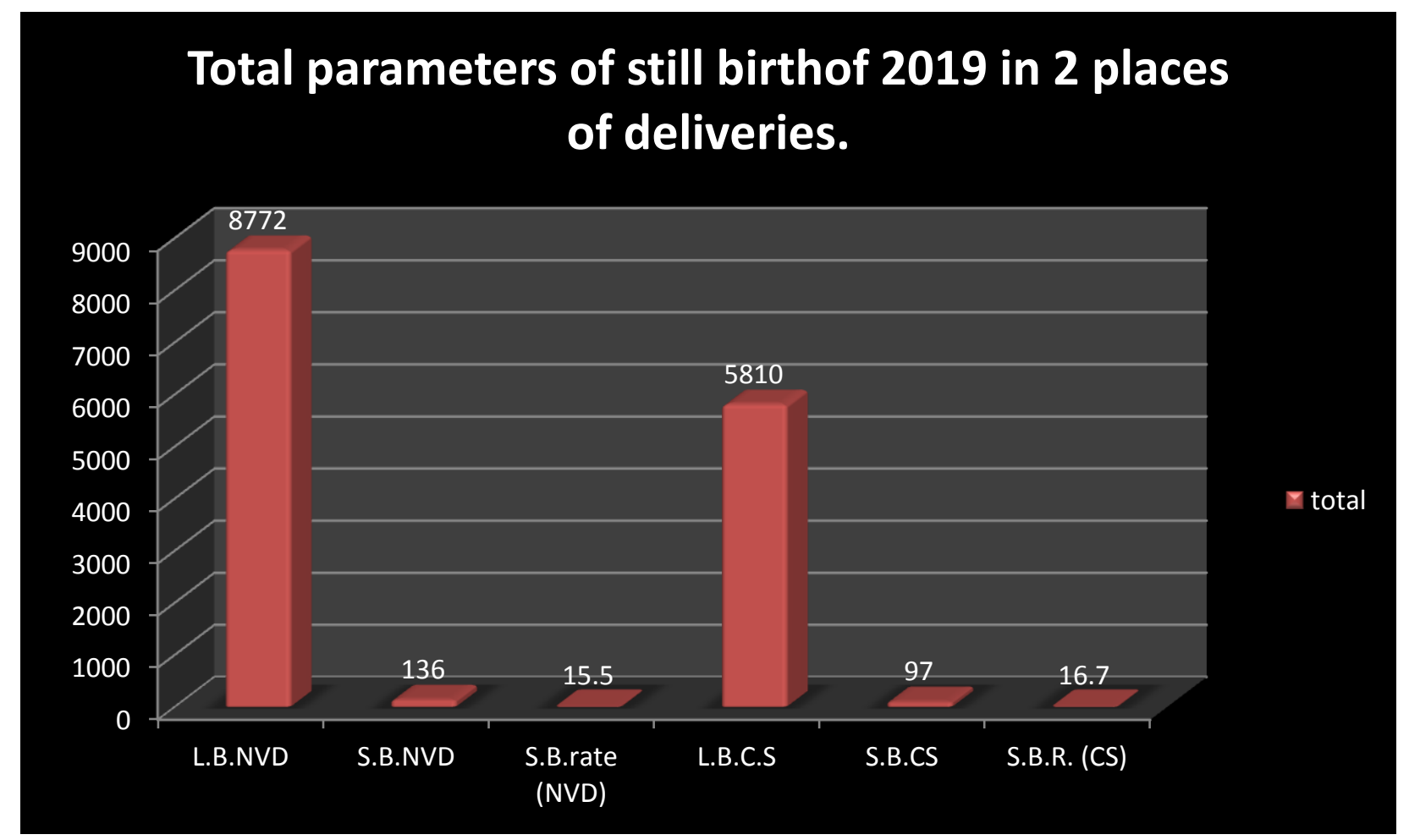

Figure 2: Difference of the total SBR in the 2 places of delivery ANOVA $=0.795 \ldots \ldots$....p value $=0.382$ 
Web Site: https://jmed.utq.edu.iq

ISSN (Print):1992-92 18, ISSN (Online):1992-92 18

DOI: https://doi.org/10.32792/utq/utjmed/19/1/13
Email:utjmed@utq.edu.iq

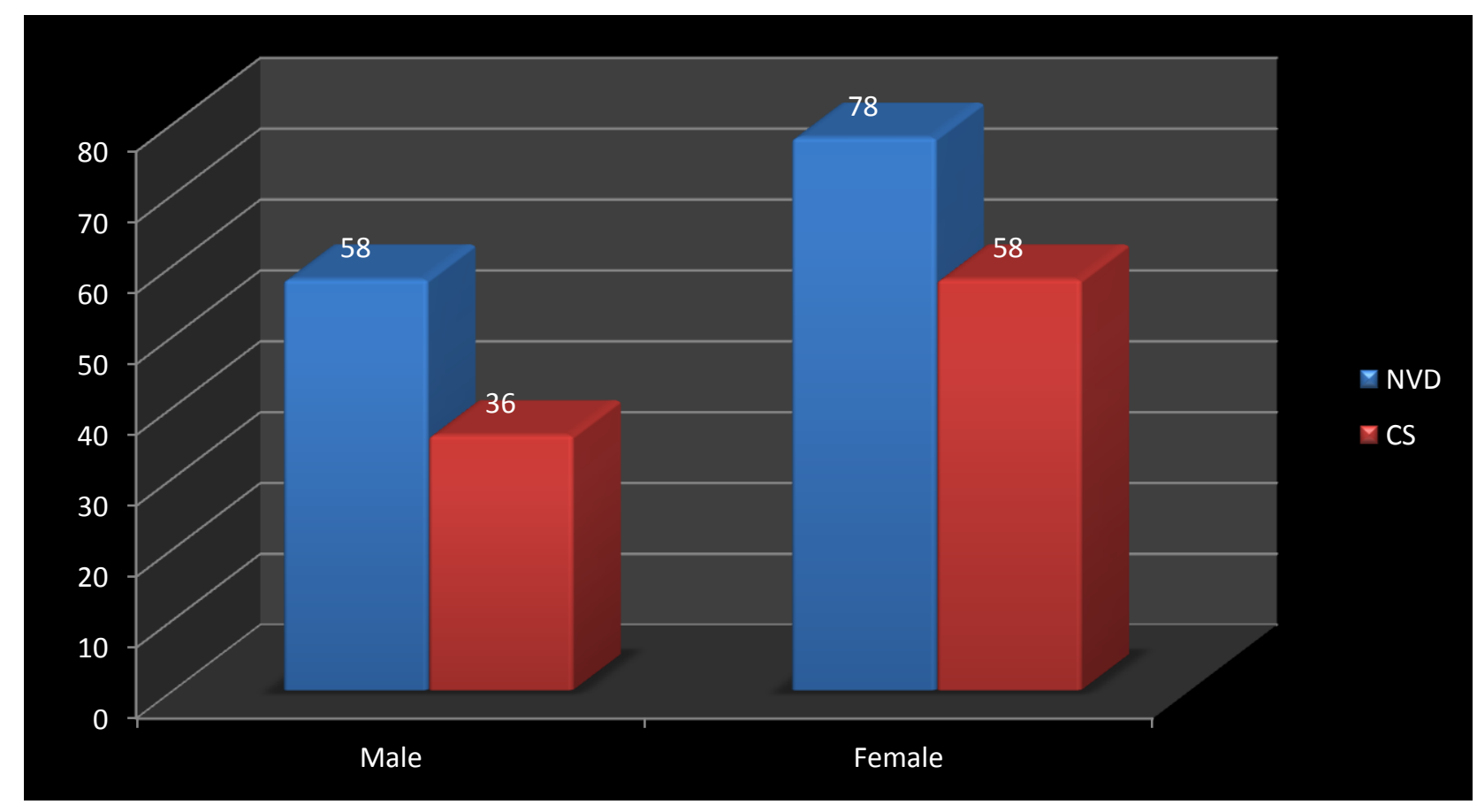

Figure 3-A: Distribution according to gender of the SB babies

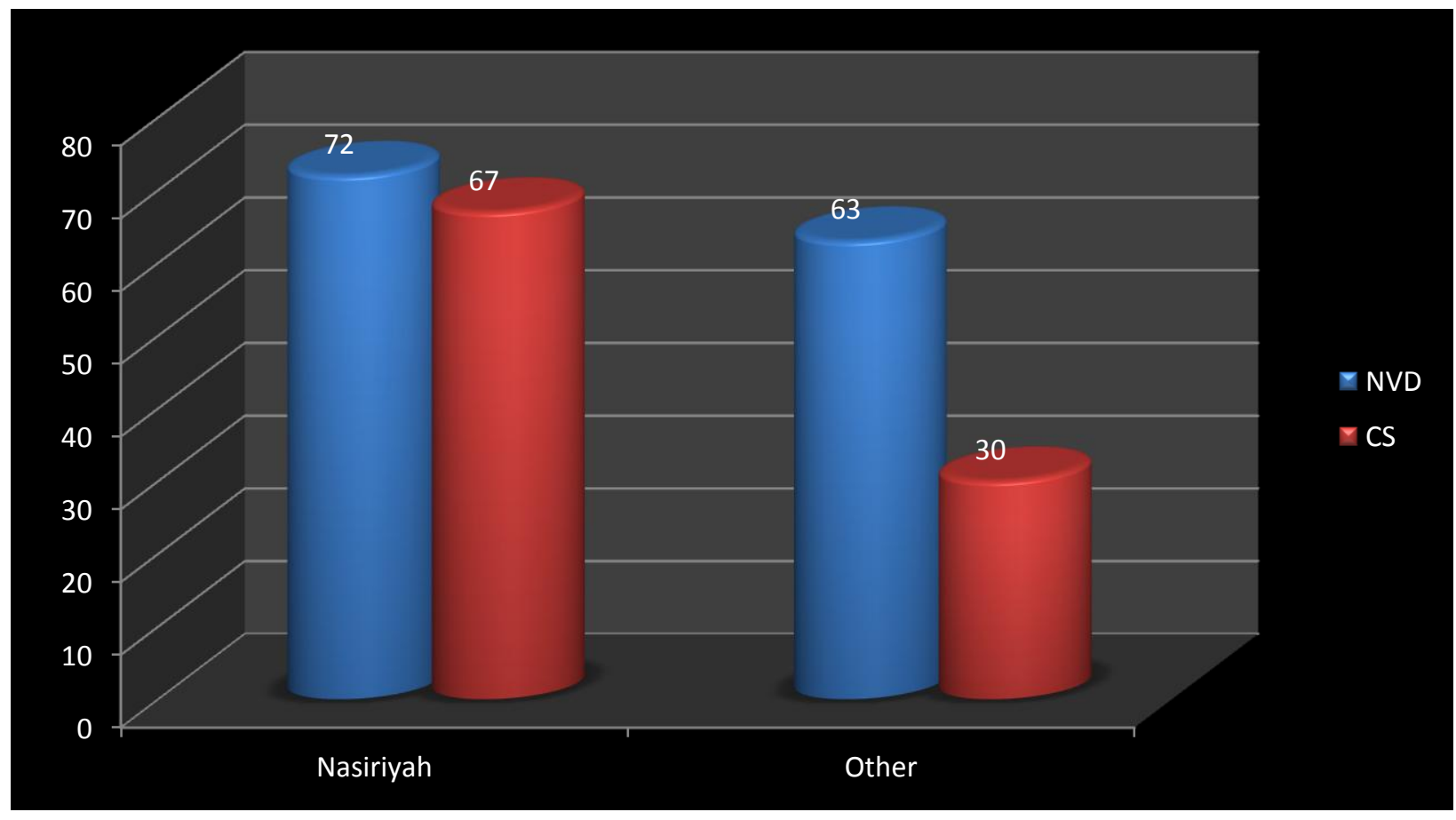

Figure3-B: Distribution according to residence of the SB fetus. 
ISSN (Print):1992-92 18, ISSN (Online):1992-92 18

DOI: https://doi.org/10.32792/utq/utjmed/19/1/13

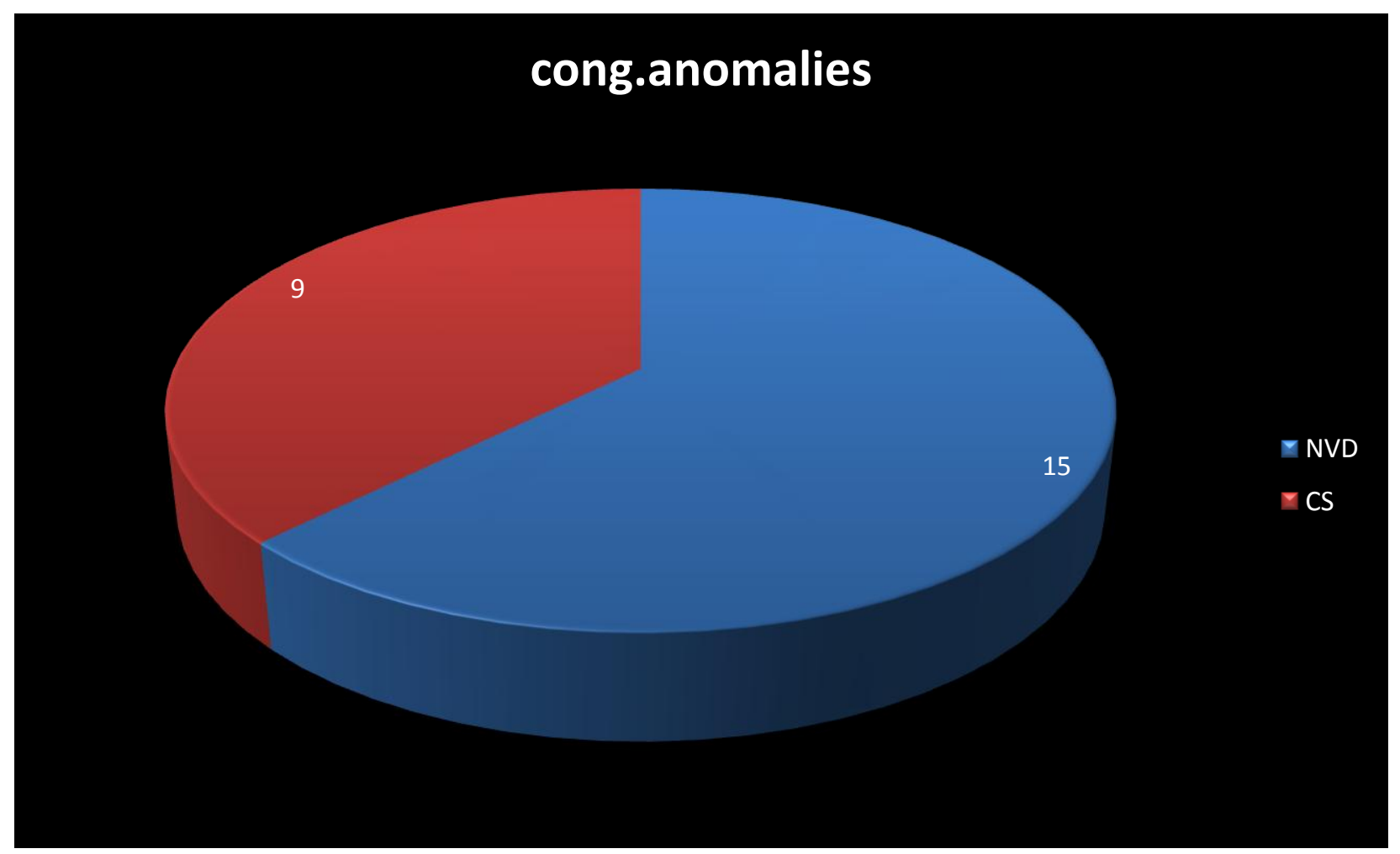

Figure 3-C: Distribution according to presence of congenital anomalies

\begin{tabular}{|c|c|c|c|c|c|c|c|c|c|}
\hline \multicolumn{10}{|c|}{$\begin{array}{l}\text { Table 2: Paired Samples Statistics analysis for the total SB in two different places of } \\
\text { delivery }\end{array}$} \\
\hline \multicolumn{2}{|c|}{ Pair } & Mean & $\mathbf{N}$ & S. D & S. E & Correlation & Sig. & $\mathbf{t}$ & p \\
\hline \multirow[t]{2}{*}{1} & $\begin{array}{l}\text { Total birth } \\
\text { NVD }\end{array}$ & 731 & 12 & 45.19 & 13.04 & .635 & .026 & 19.479 & .0001 \\
\hline & $\begin{array}{l}\text { Total birth } \\
\text { Cs }\end{array}$ & 484.2 & 12 & 55.34 & 15.97 & & & & \\
\hline \multirow[t]{2}{*}{2} & $\begin{array}{l}\text { No .of } \\
\text { S.B.NVD }\end{array}$ & 11.3 & 12 & 3.31 & .95 & .292 & .356 & 2.721 & .020 \\
\hline & S.B.CS & 8.08 & 12 & 3.62 & 1.047 & & & & \\
\hline \multirow[b]{2}{*}{3} & S.B.R.NVD & 15.54 & 12 & 4.60 & 1.32 & .220 & .492 & $-.495-$ & .630 \\
\hline & S.B.R. CS & 16.67 & 12 & 7.56 & 2.182 & & & & \\
\hline
\end{tabular}

A very high had been noted in comparison of the total birth means of the 2 different places of delivery, while the comparison of still birth number show significant statistical difference with a week positive correlation, on other hand there was no significant statistical difference between the SB Rates of 2 different place with non significant negative correlation 
Thi-Qar Medical Journal (TQMJ): Vol.(19), No.(1), 2020

Web Site: https://jmed.utq.edu.iq

Email:utjmed@utq.edu.iq

ISSN (Print):1992-92 18, ISSN (Online):1992-92 18

DOI: https://doi.org/10.32792/utq/utjmed/19/1/13

Table 3- A: Comparison of still birth rates according to type of deliveries and weights of born baby and months of 2019

\begin{tabular}{|l|c|c|c|c|c|c|}
\hline \multirow{2}{*}{ Months } & \multicolumn{2}{|c|}{ Wt $<1 \mathrm{Kg} \%$} & \multicolumn{2}{c|}{$1-2.5 \mathrm{Kg} \%$} & \multicolumn{2}{c|}{$>2.5 \mathrm{~kg}$} \\
\cline { 2 - 7 } & NVD & CS & NVD & CS & NVD & CS \\
\hline Jan & 0.167 & 0.4 & 0.33 & 0.2 & 0.5 & 0.4 \\
\hline Feb & 0 & 0.13 & 0.54 & 0.25 & 0.45 & 0.62 \\
\hline Mar & 0.14 & 0.25 & 0.57 & 0.5 & 0.28 & 0.25 \\
\hline Apri & 0.53 & 0.33 & 0.2 & 1 & 0.26 & 0 \\
\hline May & 0.2 & 0 & 0.4 & 0.54 & 0.4 & 0.45 \\
\hline June & 0.22 & 0.14 & 0.44 & 0.71 & 0.33 & 0.143 \\
\hline July & 0.13 & 0.06 & 0.53 & 0.62 & 0.33 & 0.32 \\
\hline August & 0.28 & 0 & 0.43 & 0.33 & 0.28 & 0.66 \\
\hline Sep. & 0.66 & 0.22 & 0 & 0.55 & 0.33 & 0.22 \\
\hline Oct. & 0.38 & 0.09 & 0.31 & 0.64 & 0.31 & 0.27 \\
\hline Nov & 0.66 & 0 & 0 & 0.4 & 0.33 & 0.6 \\
\hline Dec & 0.07 & 0.44 & 0.57 & 0.11 & 0.35 & 0.44 \\
\hline
\end{tabular}

Table 3- B: Paired sample statistics comparison of still birth rates according to type of deliveries and weights of borne baby and months

\begin{tabular}{|c|c|c|c|c|c|c|c|}
\hline & \multicolumn{5}{|c|}{ Paired Differences } & \multirow{3}{*}{$\begin{array}{c}\text { Sig. } \\
\text { (2-tailed) }\end{array}$} \\
\hline & & & \multirow[t]{2}{*}{ S. D } & \multirow{2}{*}{$\begin{array}{l}\text { Correl } \\
\text { ation }\end{array}$} & \multirow[t]{2}{*}{ Sig. } & \multirow[b]{2}{*}{$\mathrm{t}$} & \\
\hline & & & & & & & \\
\hline Pair 1 & $\begin{array}{l}\text { Less } 1 \mathrm{Kg}(\mathrm{NVD}) \text { - } \\
\text { less } 1 \mathrm{kgCS}\end{array}$ & .11475 & .293 & $-.168-$ & .601 & 1.356 & .202 \\
\hline Pair 2 & $\begin{array}{l}\text { bet. } 1 \text { to } 2.5 \mathrm{~kg}(\mathrm{NVD}) \\
- \text { bet } 1 \text { to } 2.5 \mathrm{kgCS}\end{array}$ & $-.12750-$ & .362 & $-.290-$ & .360 & $-1.219-$ & .248 \\
\hline Pair 3 & $\begin{array}{l}\text { More } 2.5 \mathrm{~kg}(\mathrm{NVD}) \\
\text { - More } 2.5 \mathrm{KgCS}\end{array}$ & $-.01858-$ & .185 & .395 & .204 & $-.346-$ & .736 \\
\hline Pair 4 & $\begin{array}{l}\text { less } 1 \mathrm{Kg}- \\
\text { bet.1to } 2.5 \mathrm{~kg} \\
\text { (NVD) }\end{array}$ & $-.07358-$ & .420 & $-.951-$ & .000 & $-.606-$ & .557 \\
\hline Pair 5 & $\begin{array}{l}\text { less } 1 \mathrm{Kg}-\text { More } \\
2.5 \mathrm{~kg}(\mathrm{NVD})\end{array}$ & $-.05942-$ & .262 & $-.436-$ & .156 & $-.785-$ & .449 \\
\hline Pair 6 & $\begin{array}{l}\text { less } 1 \mathrm{kgCS}-\text { bet. } \\
1 \text { to } 2.5 \mathrm{kgCS}\end{array}$ & $-.31583-$ & .314 & $-.172-$ & .593 & $-3.479-$ & .005 \\
\hline Pair 7 & $\begin{array}{l}\text { less } 1 \mathrm{kgCS}-\text { More } \\
2.5 \mathrm{KgCS}\end{array}$ & $-.19275-$ & .301 & $-.410-$ & .186 & $-2.213-$ & .049 \\
\hline Pair 8 & $\begin{array}{l}\text { bet. } 1 \text { to } 2.5 \mathrm{~kg}- \\
\text { More } 2.5 \mathrm{~kg} . . \\
\text { (NVD) }\end{array}$ & .01417 & .205 & .137 & .672 & .239 & .815 \\
\hline Pair 9 & $\begin{array}{l}\text { Bet. } 1 \text { to } 2.5 \mathrm{kgCS}- \\
\text { More } 2.5 \mathrm{KgCS}\end{array}$ & .12308 & .424 & $-.780-$ & .003 & 1.005 & .337 \\
\hline
\end{tabular}


Thi-Qar Medical Journal (TQMJ): Vol.(19), No.(1), 2020

Web Site: https://jmed.utq.edu.iq

Email:utjmed@utq.edu.iq

ISSN (Print):1992-92 18, ISSN (Online):1992-92 18

DOI: https://doi.org/10.32792/utq/utjmed/19/1/13

Only the body weight of the less than one and from 1-2.5 kg in CS group and less $1 \mathrm{kgCS}$ - More $2.5 \mathrm{KgCS}$ show significant statistical differences.

Table 4- A: Comparison of still birth rates according to mother age in different months of 2019

\begin{tabular}{|c|c|c|c|c|c|c|}
\hline \multirow[t]{2}{*}{ Months } & \multicolumn{2}{|c|}{ Mother age $<20$ yrs } & \multicolumn{2}{|c|}{ Bet. $20-40$ yrs } & \multicolumn{2}{|c|}{$>40 \mathrm{yrs}$} \\
\hline & NVD & CS & NVD & CS & NVD & CS \\
\hline Jan & 0.166667 & 0 & 0.833333 & 1 & 0 & 0 \\
\hline Feb & 0.272727 & 0 & 0.727273 & 1 & 0 & 0 \\
\hline Mar & 0.214286 & 0 & 0.785714 & 1 & 0 & 0 \\
\hline Apri & 0.066667 & 0 & 0.933333 & 1 & 0 & 0 \\
\hline May & 0.1 & 0 & 0.9 & 1 & 0 & 0 \\
\hline June & 0.222222 & 0.142857 & 0.777778 & 0.857143 & 0 & 0 \\
\hline July & 0.2 & 0.0625 & 0.8 & 0.6875 & 0 & 0 \\
\hline August & 0.071429 & 0 & 0.928571 & 1 & 0 & 0 \\
\hline Sep. & 0.111111 & 0.111111 & 0.888889 & 0.888889 & 0 & 0 \\
\hline Oct. & 0 & 0 & 0.846154 & 1 & 0 & 0 \\
\hline Nov & 0.333333 & 0 & 0.5 & 1 & 0.166667 & 0 \\
\hline Dec & 0.142857 & 0.222222 & 0.714286 & 0.777778 & 0.142857 & 0 \\
\hline
\end{tabular}


ISSN (Print):1992-92 18, ISSN (Online):1992-92 18

DOI: https://doi.org/10.32792/utq/utjmed/19/1/13

\begin{tabular}{|c|c|c|c|c|c|c|c|}
\hline \multicolumn{2}{|c|}{ Mother age } & Mean & S. D & Correl & sig & $\mathrm{t}$ & $\mathrm{P}$ value \\
\hline \multirow[t]{2}{*}{ Pair 1} & $<20 \mathrm{yr}$ & .1584 & .095 & .038 & .907 & 3.308 & .007 \\
\hline & $<20 \mathrm{CS}$ & .0449 & .074 & & & & \\
\hline \multirow[t]{2}{*}{ Pair 2} & 20 to $40 \mathrm{yr}$ & .8029 & .120 & .103 & .750 & $-2.975-$ & .013 \\
\hline & 20 to $40 \mathrm{CS}$ & .9343 & .107 & & & & \\
\hline \multirow[t]{2}{*}{ Pair 3} & $>40 \mathrm{yr}$ & .0258 & .060 & . & . & 1.478 & .167 \\
\hline & $>40 \mathrm{CS}$ & .0000 & .000 & & & & \\
\hline \multirow[t]{2}{*}{ Pair 4} & $<20 \mathrm{yr}$ & .1584 & .095 & $-.813-$ & .001 & $-10.88-$ & .000 \\
\hline & 20 to $40 \mathrm{yr}$ & .8029 & .120 & & & & \\
\hline \multirow[t]{2}{*}{ Pair 5} & $<20 \mathrm{yr}$ & .1584 & .095 & .425 & .168 & 5.197 & .000 \\
\hline & $>40 \mathrm{yr}$ & .0258 & .060 & & & & \\
\hline \multirow[t]{2}{*}{ Pair 6} & $<20 \mathrm{CS}$ & .0449 & .074 & $-.745-$ & .005 & $-17.99-$ & .000 \\
\hline & 20 to $40 \mathrm{CS}$ & .9343 & .107 & & & & \\
\hline \multirow[t]{2}{*}{ Pair 7} & $<20 \mathrm{CS}$ & .0449 & .074 & . & . & 2.074 & .062 \\
\hline & $>40 \mathrm{CS}$ & .0000 & .000 & & & & \\
\hline \multirow[t]{2}{*}{ Pair 8} & 20 to $40 \mathrm{CS}$ & .9343 & .107 & . & . & 30.008 & .000 \\
\hline & $>40 \mathrm{CS}$ & .0000 & .000 & & & & \\
\hline \multirow[t]{2}{*}{ Pair 9} & 20 to $40 \mathrm{yr}$ & .8029 & .120 & $-.791-$ & .002 & 15.657 & .000 \\
\hline & $>40 \mathrm{yr}$ & .0258 & .060 & & & & \\
\hline
\end{tabular}

The only age of the mother with more than 40 years among different places of delivery and the age of 20 with more than 40 among CS group show non-significant statistical association while the other relation between different age groups in different places and within the same place show a highly significant statistical association, regarding the correlations was of strong negative values within 3 groups as seen with in the table 4-B. 
Thi-Qar Medical Journal (TQMJ): Vol.(19), No.(1), 2020

Web Site: https://jmed.utq.edu.iq

Email:utjmed@utq.edu.iq

ISSN (Print):1992-92 18, ISSN (Online):1992-92 18

DOI: https://doi.org/10.32792/utq/utjmed/19/1/13

Table 5- A: Comparison of still birth rates according to father age borne baby in different months

\begin{tabular}{|c|c|c|c|c|c|c|}
\hline \multirow[t]{2}{*}{ Months } & \multicolumn{2}{|c|}{ Father age $<20$ yrs } & \multicolumn{2}{|c|}{ Bet. $20-40$ yrs } & \multicolumn{2}{|c|}{$>40 \mathrm{yrs}$} \\
\hline & NVD & CS & NVD & CS & NVD & CS \\
\hline Jan & 0 & 0 & 0 & 0 & 1 & 1 \\
\hline Feb & 0 & 0 & 0 & 0 & 1 & 1 \\
\hline Mar & 0 & 0 & 0.071429 & 0 & 0.857143 & 1 \\
\hline Apri & 0 & 0 & 0 & 0 & 0.933333 & 1 \\
\hline May & 0 & 0 & 0 & 0 & 0.9 & 0.909091 \\
\hline June & 0 & 0 & 0 & 0 & 0.888889 & 1 \\
\hline July & 0 & 0 & 0.066667 & 0 & 0.866667 & 0.9375 \\
\hline August & 0 & 0 & 0 & 0 & 0.928571 & 1 \\
\hline Sep. & 0 & 0 & 0 & 0 & 1 & 1 \\
\hline Oct. & 0 & 0 & 0.153846 & 0 & 0.846154 & 1 \\
\hline Nov & 0.166667 & 0 & 0 & 0 & 1 & 1 \\
\hline Dec & 0.142857 & 0 & 0 & 0 & 1 & 1 \\
\hline
\end{tabular}


Thi-Qar Medical Journal (TQMJ): Vol.(19), No.(1), 2020

Web Site: https://jmed.utq.edu.iq

Email:utjmed@utq.edu.iq

ISSN (Print):1992-92 18, ISSN (Online):1992-92 18

DOI: https://doi.org/10.32792/utq/utjmed/19/1/13

Table 5- B: Paired Samples Statistics Comparison of still birth rates according to father age borne baby in different months

\begin{tabular}{|c|c|c|c|c|c|c|c|}
\hline Pairs & Father age & Mean & S. D & $\begin{array}{l}\text { Corr } \\
\text { el. }\end{array}$ & Sig. & $\mathbf{t}$ & $\mathbf{P}$ \\
\hline \multirow[t]{2}{*}{ Pair1 } & $<20$ NVD & .0258 & .06045 & & & 1.478 & .167 \\
\hline & $20 \mathrm{CS}$ & .0000 & .00000 & & & & \\
\hline \multirow[t]{2}{*}{ Pair2 } & 20-40 NVD & .0243 & .04872 & & & 1.730 & .112 \\
\hline & 20-40-CS & .0000 & .00000 & & & & \\
\hline \multirow[t]{2}{*}{ Pair3 } & $>41 \mathrm{NVD}$ & .9351 & .06263 & .356 & .257 & $-3.057-$ & .011 \\
\hline & $>41-\mathrm{CS}$ & .9872 & .03047 & & & & \\
\hline \multirow[t]{2}{*}{ Pair 4} & $<20$ NVD & .0258 & .06045 & $-.232-$ & .467 & .059 & .954 \\
\hline & 20-40 NVD & .0243 & .04872 & & & & \\
\hline \multirow[t]{2}{*}{ Pair 5} & $<20-$ NVD & .0258 & .06045 & .483 & .112 & $-50.292-$ & .0001 \\
\hline & $>41 \mathrm{NVD}$ & .9351 & .06263 & & & & \\
\hline \multirow[t]{2}{*}{ Pair 6} & 20-40 NVD & .0243 & .04872 & $-.709-$ & .010 & $-30.608-$ & .0001 \\
\hline & $>41 \mathrm{NVD}$ & .9351 & .06263 & & & & \\
\hline \multirow[t]{2}{*}{ Pair 7} & $<20-\mathrm{CS}$ & $.0000^{\mathrm{a}}$ & .00000 & & & 1.478 & .167 \\
\hline & $20-40-C S$ & $.0000^{\mathrm{a}}$ & .00000 & & & & \\
\hline \multirow[t]{2}{*}{ Pair 8} & $<20 \mathrm{CS}$ & .0000 & .00000 & & & $112.253^{-}$ & .0001 \\
\hline & $>41-\mathrm{CS}$ & .9872 & .03047 & & & & \\
\hline \multirow[t]{2}{*}{ Pair 9} & 20-40-CS & .0000 & .00000 & & & $112.253^{-}$ & .0001 \\
\hline & $>41-\mathrm{CS}$ & .9872 & .03047 & & & & \\
\hline
\end{tabular}


Web Site: https://jmed.utq.edu.iq

ISSN (Print):1992-92 18, ISSN (Online):1992-92 18

DOI: https://doi.org/10.32792/utq/utjmed/19/1/13
Email:utjmed@utq.edu.iq

\section{Discussion}

The current study show little non- significant difference between the SBRs of NVD \& CS through which the total values of both was 15,5 and $16.7 / 1000$ respectively, which was lower than Sarah S. \& Shiyam Sunder Tikmani, et al ${ }^{(13)}$ study reviewed the trend of SBR mean of 2010 - 2016, that decreased from 31.7 to $26.4 / 1000$ births , where reduction average annually by nearly $3.0 \%$ .this difference of the our SBR and Sarah et al study migh be explained by the difference in the study design or difference in the community characters that are reviewed by the 2 studies but our study was nearest to goal by the year of 2030 of The Every Newborn Action Plan, a to reduce SBR at global level to $12 / 1000$ births $^{(14,15)}$. If we assume a rate of 12/1000 births by 2030 .

In our study the SBR dosn't show significant decline or increment all over the 12 months of the study, this was not comparable to many studies especially Blencowe et al study, that done using thousand number of data envolving large number of countries (195) between the years of 2005-2015

Regarding the SBR we register lower rate than Pakistan ( 43.1per thousand births) also S.Saleem et al register a SBR at 2016 as 47.7/1000 births. In India -different states SBR (20- 66/1000), the stillbirth rates in different states reportedly range from births. Bellad et al- from Karnataka(also Indian sites).( 28.6/1000) births[16]. it also lower than mean SBR for many Indian states which (25.3/1000) births But, Our study result was comparable to Nagpur- Maharashtra district ( 17.8/1000 )births...and also nearly comparable to Kenya national SBR as WHO reporting $(21.8 / 1000)$ births $^{(17)}$ \& lower thann Zambia (25.5/1000) births ${ }^{(18)}$.

The national SBR Guatemala reporting (10/1000) births which was lower than our study ${ }^{(8)}$. This variation might be explained by the differences in the population characteristics, sample size and design of the study.

Parents age of more than 40 was one of the main contributors of the SBR in different places, regardless the place of delivery was the main significant finding of our study, which comparable to other studies where consider as independent risk of $\mathrm{SB}^{(2,5,19)}$ Regarding the antenatal care coverage rate was low in our society, public sector of health suffering from scarcity of resources regarding the availability of supplements, diagnostic tools and treatment, that convert the pregnant vision to private sectors, which make difficult decision to convey the role of ANC in reduction of $\mathrm{SBR}$, in Iraq. That surely make a differences from other studies Kenya, Pakistan and Zombia $^{(20)}$ that focusing on the role of ANC on outcome of pregnancy

\section{Limitation:}

1- To an unknown extent the deliveries with home or mid wife deliveries was deficult tobe predicted

2- $\quad$ Private sectors regarding the deliveries by CS or deliver by Painless clinic also don't enter in our research.

\section{Conclusion:}

1- There was no significant statistical difference of the SBR with in the 2 places of delivery

2- There was no difference in monthly trends of SBR all-over the priod of the study, whether was by CS or NVD.

3- Different age groups in different places and within the same place show a highly significant statistical association, B. wt. of deliverd baby was also one of the main determinants of the SBR and the age of father 
ISSN (Print):1992-92 18, ISSN (Online):1992-92 18

DOI: https://doi.org/10.32792/utq/utjmed/19/1/13

that extending the 41 years show significant

difference in the occurance of the SB..

\section{$\underline{\text { References }}$}

1. International Classification of Disease 10th Revision (ICD-10) [Internet]. 2010. Available from: http ://www.who.int/classifications/icd/ICD10Volume2_en_2010.pdf?ua-1. [cited Dec 12, 2017].

2. Lawn JE, Blencowe H, Waiswa P, Amouzou A, Mathers C, Hogan D, et al. Stillbirths: rates, risk factors, and acceleration towards 2030. Lancet. 2016;387(10018):587-603. doi: 10.1016/S01406736(15)00837-5. [PubMed] [CrossRef] [Google Scholar]

3. Goldenberg RL, Saleem S, Pasha O, Harrison MS, Mcclure EM. Reducing stillbirths in lowincome countries. Acta Obstet Gynecol Scand. 2016;95(2):135-143. doi: 10.1111/aogs.12817. [PubMed] [CrossRef] [Google Scholar]

4. Aminu M, Unkels R, Mdegela M, Utz B, Adaji S, den Broek N. Causes of and factors associated with stillbirth in low-and middle-income countries: a systematic literature review. BJOG Int J Obstet Gynaecol. 2014;121(s4):141-153. doi: 10.1111/1471-0528.12995. [PubMed] [CrossRef] [Google $\underline{\text { Scholar }]}$

5. Flenady V, Koopmans L, Middleton P, Frøen JF, Smith GC, Gibbons K, et al. Major risk factors for stillbirth in high-income countries: a systematic review and metaanalysis. Lancet. 2011;377(9774):1331-1340. doi: 10.1016/S0140-6736(10)62233-7. [PubMed] [CrossRef] [Google Scholar]

6. Manasyan A, Saleem S, Koso-Thomas M, Althabe F, Pasha O, Chomba E, et al. Assessment of obstetric and neonatal health services in developing country health facilities. Am J Perinatol. 2013;30(09):787-794. doi: 10.1055/s-0032-1333409. [PMC free article] [PubMed] [CrossRef] [Google Scholar]

7. Lawn JE, Blencowe H, Pattinson R, Cousens S, Kumar R, Ibiebele I, et al. Stillbirths: where? when? why? How to make the data count? Lancet. 2011;377(9775):1448-1463. doi: 10.1016/S01406736(10)62187-3. [PubMed] [CrossRef] [Google Scholar]

8. Blencowe H, Cousens S, Jassir FB, Say L, Chou D, Mathers C, et al. National, regional, and worldwide estimates of stillbirth rates in 2015, with trends from 2000: a systematic analysis. Lancet Glob Health. 2016;4(2):e98-e108. doi: 10.1016/S2214-109X(15)00275-2. [PubMed] [CrossRef] [Google Scholar]

9. Saleem S, McClure EM, Bux R, Shaheed A, Goldenberg RL, Pappas G. Pregnancy behavior of pakistani women over their reproductive life span. Al Ameen J Med Sci. 2010;3:228-236. [Google $\underline{\text { Scholar] }}$

10. McClure EM, Saleem S, Goudar SS, Moore JL, Garces A, Esamai F, et al. Stillbirth rates in lowmiddle income countries 2010-2013: a population-based, multi-country study from the global network. Reprod Health. 2015;12(2):S7. doi: 10.1186/1742-4755-12-S2-S7. [PMC free article] [ubMed] [CrossRef] [Google Scholar] 
ISSN (Print):1992-92 18, ISSN (Online):1992-92 18

DOI: https://doi.org/10.32792/utq/utjmed/19/1/13

11. Pasha O, Saleem S, Ali S, Goudar SS, Garces A, Esamai F, et al. Maternal and newborn outcomes in Pakistan compared to other low and middle income countries in the global Network's maternal newborn health registry: an active, community-based, pregnancy surveillance mechanism. Reprod Health. 2015;12(2):S15. doi: 10.1186/1742-4755-12-S2-S15. [PMC free article] [PubMed] [CrossRef] [Google Scholar]

12. McClure EM, Saleem S, Pasha O, Goldenberg RL. Stillbirth in developing countries: a review of causes, risk factors and prevention strategies. J Matern Fetal Neonatal Med. 2009;22(3):183-190. doi: 10.1080/14767050802559129. [PMC free article] [PubMed] [CrossRef] [Google Scholar)

13. Sarah Saleem, $\otimes^{1}$ Shiyam Sunder Tikmani,${ }^{1}$ Elizabeth M. McClure et al, Trends and determinants of stillbirth in developing countries: results from the Global Network's Population-Based Birth Registry, Reprod Health. 2018; 15(Suppl 1): 100. Published online 2018 Jun 22. doi: $\underline{10.1186 / \mathrm{s} 12978-018-0526-3}$ PMCID: PMC6019981, PMID: 29945647

14. WHO U . Every newborn: an action plan to end preventable newborn deaths. Geneva: World Health Organization; 2014. [Google Scholar]

15. Chou D, Daelmans B, Jolivet RR, Kinney M, Say L. Ending preventable maternal and newborn mortality and stillbirths. BMJ. 2015;351:h4255. doi: 10.1136/bmj.h4255. [PubMed] [CrossRef] [Google Scholar].

16. Bellad MB, Vidler M, Honnungar NV, Mallapur A, Ramadurg U, Charanthimath U, et al. Maternal and newborn health in Karnataka state, India: the community level interventions for preeclampsia (CLIP) Trial's baseline study results. PLoS One. 2017;12(1):e0166623. doi: 10.1371/journal.pone.0166623. [PMC free article] [PubMed] [CrossRef] [Google Scholar]

17. Demographic K. Health survey 2008-2009. 2010. Kenya Service Provision Assessment: Nairobi; 2015. [Google Scholar]

18. Demographic Z . Central statistical office, central Board of Health, and ORC macro Calverton. Maryland: Demographic Z; 2003. Health Survey 2001-2002. [Google Scholar]

19. Stillbirth Collaborative Research Network Writing Group. Association between stillbirth and risk factors known at pregnancy confirmation. JAMA. 2011;306(22):2469-79. [PMC free $\underline{\text { article] }}[$ PubMed]

20. Stringer EM, Vwalika B, Killam WP, Giganti MJ, Mbewe R, Chi BH, et al. Determinants of stillbirth in Zambia. Obstet Gynecol. 2011;117(5):1151-1159. doi: 10.1097/AOG.0b013e3182167627. [PubMed] [CrossRef] [Google Scholar] 


\section{الاختلافات في معدل المواليد الساكنة بين الولادة القيصرية والولادة المهبلية

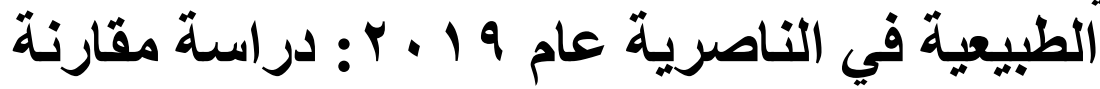

د.فلاح عبد بشيز الحمداني

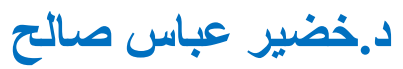

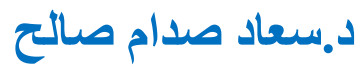

وزارة الصحة ــ دائرة صحة ذي قار - مستثفى بنت الهدى التعليمي

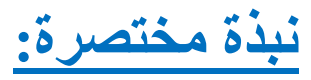

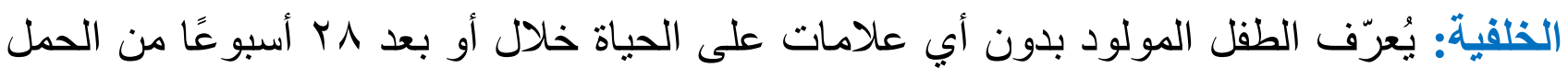

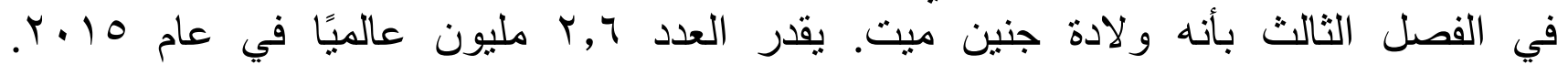

الأهداف: مقارنة حسب مكان الو لادة في مدينة الناصرية وتحديد المحددات المتوقعة للمو اليد الميتة.

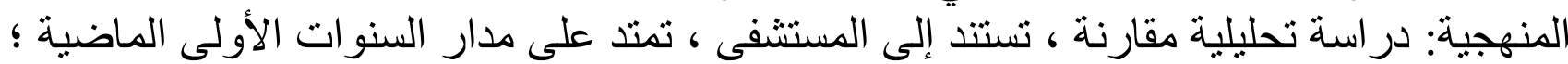

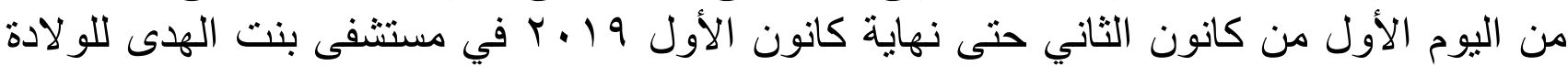

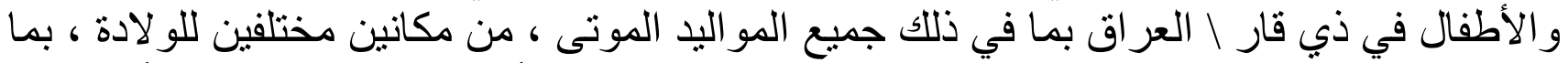

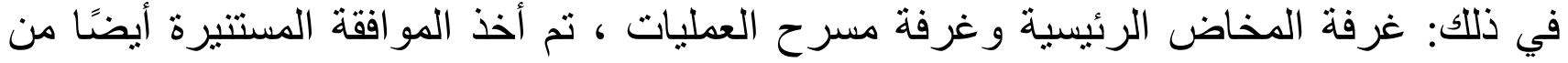

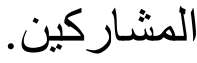
الو الدين

جميع نان

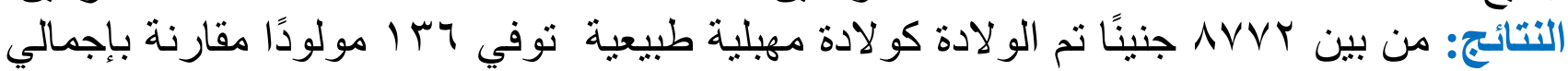

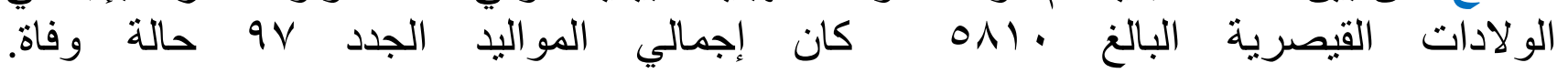

لا يزال الاختلاف في معدلات المو اليد ليس ذا قيمة كبيرة في توزيعها وفقًا للأشهر والمو اسم r. 19 لعام

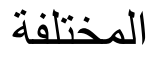

الاستنتاج: لايظهر بين الولادة القيصرية والولادة المهبلية الطبيعية أب فرق إحصائي كبير. 